\title{
Produksi Pigmen Klorofil Terenkapsulasi dari Daun Kangkung (Ipomea reptans Poir.) Dengan Teknik Mikroenkapsulasi
}

\author{
Encapsulated Chlorophyll Pigment Production from Kangkung Leaf (Ipomea reptans \\ Poir.) With Microencapsulation Technique
}

\author{
Desy Nurliasari ${ }^{1)}$, Damar Wiraputra ${ }^{2)}$ \\ 1) Jurusan Teknologi Industri Pangan Fakultas Teknologi Industri Pertanian Universitas Padjadjaran \\ Jl. Raya Bandung Sumedang KM.21, Hegarmanah, Jatinangor, Kabupaten Sumedang, Jawa Barat 45363 \\ ${ }^{2)}$ Alumni Jurusan Teknologi Industri Pangan Universitas Padjadjaran \\ Email korespondensi: desy.nurliasari@gmail.com
}

\begin{abstract}
Abstrak
Daun kangkung mengandung pigmen klorofil yang dapat dimanfaatkan sebagai pewarna alami untuk makanan. Ekstrak pekat pigmen klorofil dari daun kangkung merupakan bahan yang sangat kental sehingga agak sulit dan kurang praktis dalam penggunaannya. Hal ini dapat diatasi dengan manggunakan teknik mikroenkapsulasi sehingga mempermudah penggunaan dan meningkatkan umur simpannya. Bahan penyalut yang digunakan untuk mikroenkapsulasi ekstrak pigmen klorofil ini adalah dekstrin dan gum arab. Metode yang digunakan pada penelitian ini adalah deskriptif dengan 6 perlakuan dan 2 kali ulangan. Perlakuan yang digunakan adalah penggunaan bahan penyalut dekstrin dengan konsentrasi $5 \%, 7,5 \%$, dan $10 \%$ (b/v) dan gum arab dengan konsentrasi 5\%, 7,5\%, dan $10 \%$ (b/v) dari total volume bahan. Hasil penelitian menunjukan penggunaan bahan penyalut dekstrin dengan konsentrasi $10 \%(\mathrm{~b} / \mathrm{v})$ menghasilkan bubuk pigmen klorofil dari daun kangkung dengan karakteristik terbaik, yaitu memiliki nilai intensitas warna hijua (nilai a) yaitu - 19.97, nilai HUE 127.42 (melefleksikan warna kuning kehijauan), rendemen 2.99\%, kadar air 1,80\%, kelarutan 97.48\%, waktu rehidrasi 36.4 detik, dan nilai pH 8,1.
\end{abstract}

\section{Kata kunci : daun kangkung, dekstrin, gum arab, mikroenkapsulasi} Abstract

Water spinach leaves contain chlorophyll pigments which can be used as natural coloring for food. Concentrated extract of chlorophyll pigment from kale leaves is a very thick material that is rather difficult and less practical in its use. This can be overcome by using microencapsulation techniques so as to facilitate use and increase shelf life. The coating material used for microencapsulation of chlorophyll pigment extract is dextrin and arabic gum. The method used in this study is descriptive with 6 treatments and 2 repetitions. The treatment used was the use of dextrin coating material with a concentration of $5 \%, 7.5 \%$, and $10 \%(\mathrm{~b} / \mathrm{v})$ and arabic gum with a concentration of $5 \%, 7.5 \%$, and $10 \%$ (b / v) of the total volume. ingredients. The results showed that the use of dextrin coating material with a concentration of $10 \%(\mathrm{w} / \mathrm{v})$ produced chlorophyll pigment powder from kale leaves with the best characteristics, which has hijua color intensity value (a value), namely - 19.97, HUE value 127.42 (reflecting greenish yellow), yield $2.99 \%$, water content $1.80 \%$, solubility $97.48 \%$, rehydration time 36.4 seconds, and $\mathrm{pH}$ value 8.1.

Keywords: Water spinach leave, dextrin, gum arabic, microencapsulation

\section{Pendahuluan}

Penentuan mutu bahan pangan pada umumnya sangat tergantung pada beberapa faktor seperti cita rasa, tekstur, nilai gizi dan sifat mikrobiologisnya, tetapi sebelum faktor-faktor lain dipertimbangkan, secara visual faktor warna tampil lebih dahulu dan sangat menentukan. Ada beberapa hal yang dapat menyebabkan suatu bahan pangan berwarna antara lain dengan penambahan zat warna. Akan tetapi, seringkali terjadi penyalahgunaan pemakaian zat warna untuk bahan pangan, misalnya zat pewarna untuk tekstil dan kulit dipakai untuk mewarnai bahan pangan. Timbulnya 
penyalahgunaan tersebut dikarenakan zat warna sintetis jauh lebih murah dan warnanya lebih menarik (Cahyadi, 2006).

Pewarna sintetis mulai dikembangkan pada pertengahan abad ke-19 dan banyak digunakan dalam industri makanan karena lebih ekonomis, praktis dan menghasilkan warna yang stabil dan homogen. Penelitian lebih lanjut menemukan adanya efek negatif penggunaan beberapa pewarna sintetis yang dapat membahayakan kesehatan (Wirakusumah, 2004).

Saat ini telah banyak pewarna sintetis yang dilarang penggunaannya di beberapa negara karena masih dipertanyakan keamanannya. Hal tersebut mendorong pemanfaatan pigmen sebagai pewarna alami dalam industri makanan. Klorofil merupakan salah satu pigmen hasil produksi tanaman berdaun hijau yang dijadikan sebagai indikator kematangan dan kesehatan sehingga memiliki potensi untuk diaplikasikan sebagai pewarna dalam industri makanan.

Daun kangkung memiliki potensi untuk dimanfaatkan sebagai pewarna alami karena warna hijaunya. Kangkung (Ipomoea reptans Poir.), merupakan sejenis tumbuhan yang termasuk jenis sayur-sayuran. Proses penanaman kangkung dapat dilakukan di darat maupun di air. Kangkung banyak terdapat di kawasan Asia dan merupakan tumbuhan yang dapat dijumpai hampir di mana-mana terutama di kawasan darat (Anonim, 2009).

Warna hijau dari daun kangkung ini disebabkan oleh kandungan pigmen klorofil yang tinggi (Wirakusumah, 2004). Klorofil merupakan salah satu pigmen yang telah lama dikonsumsi manusia sebagai bagian dari buah dan sayuran tanpa efek yang membahayakan, sehingga memiliki potensi untuk diaplikasikan sebagai pewarna dalam industri makanan.

Pigmen klorofil dihasilkan dari ekstraksi dengan pelarut dengan penambahan natrium bikarbonat untuk mempertahankan warna hijaunya. Pelarut yang umum digunakan untuk ekstraksi bahan pangan dapat bersifat non polar maupun polar seperti air, aseton, etanol, dan metanol. Dalam penanganan sejumlah besar pelarut, misalnya dalam pro1duksi komersial, maka kemampuan sebagai pelarut dan toksisitas merupakan hal yang paling penting untuk diperhatikan (Sadikin, 1993).

Ekstrak klorofil yang dihasilkan berbentuk cairan, sehingga agak sulit dan kurang praktis dalam penggunaannya. Klorofil juga merupakan senyawa yang mudah mengalami kerusakan akibat adanya oksigen, cahaya dan suhu tinggi. Ekstrak klorofil dapat dipermudah pemanfaatannya dengan disalut polimer seperti karbohidrat, protein, atau lemak yang dikenal dengan istilah mikroenkapsulasi. Selain lebih praktis, pigmen terenkapsulasi juga memiliki daya tahan simpan yang lebih baik. (Canovas et al, 2005). Proses mikroenkapsulasi dengan bahan penyalut khusus dirancang untuk melindungi bahanbahan terbungkus dari faktor-faktor yang dapat menurunkan kualitas bahan (Rosenberg et al, 1990).

Menurut Gibbs et al (1999) dikutip Herwindarti (2008), pewarna yang dienkapsulasi lebih mudah penanganannya, mempunyai kelarutan yang lebih baik, stabil terhadap oksidasi, dan lebih mudah pencampurannya dalam bentuk kering sehingga aplikasinya lebih luas.

Pigmen klorofil memiliki sifat yang peka terhadap panas maka untuk bahan penyalut yang dipilih harus memiliki sifat larut dalam air dingin dan tidak bereaksi dengan bahan yang disalut. Bahan penyalut yang memiliki kriteria ini diantaranya dekstrin, gum arab, CMC, dan pati termodifikasi lainnya.

Menurut Rosalianty (2008), gum arab dan dekstrin membentuk larutan bahan penyalut yang encer, sedangkan CMC membentuk larutan bahan penyalut yang sangat kental. Bahan penyalut untuk mikroenkapsulasi harus memiliki viskositas yang rendah pada konsentrasi tinggi, sehingga zat inti dapat terlarut sempurna. Metode mikroenkapsulasi ini dapat meningkatkan kestabilan pigmen klorofil selama penyimpanan.

Berdasarkan uraian diatas perlu dilakukan penelitian untuk mencari kondisi optimum ekstraksi, pelarut yang digunakan, varietas terbaik dan konsentrasi bahan penyalut yang tepat sehingga dihasilkan pigmen klorofil daun kangkung terenkapsulasi yang memiliki intensitas warna hijau yang kuat, kadar air rendah, waktu rehidrasi yang singkat, rendemen tertinggi, sehingga menghasilkan karakteristik bubuk pigmen yang baik.

\section{Bahan dan Metode Penelitian}

\subsection{Waktu dan Tempat Percobaan}

Percobaan pendahuluan dilakukan pada bulan Mei 2009, sedangkan percobaan utama dilakukan pada bulan Februari 2010. Penelitian dilakukan di Laboratorium Kimia Pangan, Laboratorium Gizi dan Penilaian Indera, Laboratorium Teknologi Pengolahan Pangan, Laboratorium Keteknikan Pengolahan Pangan Jurusan Teknologi Industri Pangan, Fakultas Teknologi Industri Pertanian dan Laboratoriun Kimia Jurusan Teknik Kimia Politeknik Negeri Bandung (POLBAN).

\subsection{Bahan dan Alat Percobaan}

Bahan baku yang akan digunakan adalah tanaman 
kangkung darat (Ipomea reptans Poir.). Bahan baku pembantu yang digunakan antara lain dekstrin, gum arab, etanol teknis, dan natrium bikarbonat.

Alat yang digunakan adalah kertas Whatman no.42, kertas saring, aluminium foil, plastik wrap (cling wrap), spatula, pipet tetes, batang pengaduk, tabung reaksi, labu ukur, tabung sentrifuge, botol semprot, gelas kimia, corong Buchner, $\mathrm{pH}$ meter, oven, desikator, cawan, blender, timbangan teknis, timbangan analitis, sentrifuge, rotary vacum evaporator, Spray Dryer Eyela SD-1, chromameter, stopwatch, stirrer dan spektrofotometer Spektronik21.

\subsection{Metode Penelitian}

Metode penelitian yang digunakan adalah metode penelitian deskriptif tanpa uji lanjutan. Metode ini menggunakan 6 jenis perlakuan dengan dua kali ulangan. Perlakuan yang diujikan terhadap ekstrak daun kangkung adalah:

A : Dekstrin konsentrasi 5\% dari total volume ekstrak

B : Dekstrin konsentasi $7.5 \%$ dari total volume ekstrak

C : Dekstrin konsentrasi $10 \%$ dari total volume ekstrak

D : Gum Arab konsentrasi 5\% dari total volume ekstrak

E : Gum Arab konsentrasi 7.5\% dari total volume ekstrak

F : Gum Arab konsentrasi 10\% dari total volume ekstrak

Daun kangkung varietas kangkung darat (daun sempit) diekstraksi menggunakan pelarut etanol dengan natrium bikarbonat 1000 ppm selama 12 jam, selanjutnya dilakukan proses pemekatan dengan evaporator vakum dengan ekstrak $10 \%$ dari ekstrak awal. Hasil pemekatan 10\% dari ekatrak awal kemudian dilakukan proses enkapsulasi menggunakan spray dryer dengan bahan penyalut dekstrin dan gum arab sesuai dengan perlakuan yang telah dijabarkan diatas.

Data yang didapat dari perlakuan tersebut disajikan dalam bentuk diagram batang. Diagram batang akan menunjukan bahan penyalut dengan konsentrasi berapa yang menghasilkan produk dengan Kriteria Pengamatan

Kriteria pengamatan yang dilakukan yaitu: Sifat bubuk pigmen klorofil terenkapsulasi meliputi:

a. Intensitas warna dengan kromameter

(Hutching, 1999).

b. Rendemen bubuk pigmen (AOAC, 1984).

c. Waktu rehidrasi (Chandrayani, 2002).

\section{Hasil dan Pembahasan}

\section{Karakteristik Umum Bubuk Pigmen Klorofil Terenkapsulasi}

Produksi bubuk pigmen klorofil terenkapsulasi dari daun kangkung yang disalut dengan dekstrin dan gum arab menghasilkan karakteristik yang berbeda. Pigmen klorofil yang disalut dengan dekstrin menghasilkan produk bubuk; sedangkan pigmen klorofil yang disalut dengan gum arab terlepas dari penyalutnya sehingga menghasilkan produk bubuk yang basah setelah dilakukan pengeringan. Pelepasan pigmen klorofil dari gum arab dikarenakan bahan inti tidak tersalut sempurna dan bahan penyalut yang menggumpal. Terbentuknya gumpalan menghambat laju alir bahan pada selang spray dryer.

Menurut Glicksman (1969), gum arab memiliki berat molekul yang lebih besar dibandingkan dekstrin. Dekstrin memiliki berat molekul 4500 - 85000, sedangkan gum arab memiliki berat molekul 250000 - 1000000. Berat molekul gum arab yang lebih besar menyebabkan titik didihnya lebih tinggi daripada dekstrin sehingga gum arab lebih mudah dilarutkan pada suhu tinggi. Salah satu penanganan untuk memudahkan penyebaran gum arab yaitu menggunakan air panas untuk melarutkan gum arab (Furia, 1968). Gum arab mudah larut dalam air karena gum arab dan air memiliki titik didih yang tinggi, sedangkan etanol memiliki titik didih yang lebih rendah daripada air yaitu $78.5^{\circ} \mathrm{C}$.

Produk akhir yang basah selain disebabkan oleh bahan inti yang tidak larut sempurna dan gum arab cepat membentuk gumpalan kembali pada selang spray dryer, produk yang dihasilkan pada tabung juga bersifat basah, gosong dan menempel pada dinding tabung. Penelitian yang sama dihasilkan oleh Sadikin (1993) tentang pembuatan flavor bubuk dari pandan wangi dan Wijaya, dkk (1995) tentang pembuatan pewarna dari daun suji dan daun pandan yang menggunakan pelarut etanol bahwa gum arab sulit dilarutkan dalam etanol, gum membentuk gumpalan dalam etanol, sehingga hanya bagian luar yang basah sedangkan bagian dalam tidak basah dan sulit untuk dilarutkan.

Produksi bubuk pigmen yang disalut dengan dekstrin menghasilkan produk bubuk yang baik yaitu dilihat dari intensitas warna hijau, rendemen dari produk bubuk yang dihasilkan, kadar air yang rendah, kelarutan yang tinggi, waktu rehidrasi yang singkat, dan nilai $\mathrm{pH}$ yang sesuai dengan $\mathrm{pH}$ klorofil. Molekul dekstrin bersifat lebih mudah terdispersi menurut Satterwhite dan Twinski (1973), karena proses transglukosidasi yang terjadi 
saat pembentukan dekstrin dimana terjadi perubahan intermolekular ikatan glikosidik $\alpha$-D$(1,4)$ pada pati menjadi ikatan $\alpha-D-(1,6)$ sehingga molekul pati yang tadinya linear dan bercabang menjadi lebih banyak cabang. Cabang yang terbentuk pada suatu rantai karbon akan menurunkan kekuatan intermolekular pada molekul tersebut sehingga lebih mudah berinteraksi dengan molekul pelarut (Morrison dan Boyd, 1975).

\section{Intensitas Warna}

Warna merupakan parameter yang penting untuk melihat suatu produk apakah layak diterima atau tidak oleh konsumen. Nilai warna suatu produk dapat dilihat dari tiga parameter yaitu $L, a$, dan $b$. Notasi L (lightness) menyatakan parameter kecerahan. Nilai a (red/green) menyatakan warna campuran merah-hijau dengan nilai $+a$ (positif) dari 0 sampai 100 untuk warna merah dan nilai -a (negatif) dari 0 sampai -80 untuk warna hijau. Notasi b (yellow/blue) menyatakan warna campuran biru- kuning dengan nilai $+b$ (positif) dari 0 sampai 70 untuk warna biru dan nilai -b (negatif) dari 0 sampai -70 untuk warna kuning. Nilai HUE menyatakan daerah warna suatu bahan. Nilai analisis warna bubuk pigmen klorofil dapat dilihat pada Tabel 1 .

Tabel 1. Warna Bubuk Pigmen Klorofil dari Daun

\begin{tabular}{|l|c|c|c|c|l|}
\hline $\begin{array}{l}\text { Perlakuan } \\
\text { Kangkung. }\end{array}$ & \multicolumn{5}{|l|}{ Rata-rata Analisis Warna } \\
\cline { 2 - 6 } & $\mathbf{L}^{*}$ & $\mathbf{a}^{*}$ & $\mathbf{b}^{*}$ & HUE & $\begin{array}{l}\text { Daerah } \\
\text { Kisaran } \\
\text { Warna }\end{array}$ \\
\hline $\begin{array}{l}\text { A (Dekstrin } \\
5 \%)\end{array}$ & 69.87 & -17.11 & 27.31 & 126.58 & $\begin{array}{l}\text { Kuning } \\
\text { Kehijauan }\end{array}$ \\
\hline $\begin{array}{l}\text { B (Dekstrin } \\
7.5 \%)\end{array}$ & 71.54 & -16.64 & 27.69 & 126.92 & $\begin{array}{l}\text { Kuning } \\
\text { Kehijauan }\end{array}$ \\
\hline $\begin{array}{l}\text { C (Dekstrin } \\
10 \%)\end{array}$ & 71.36 & -19.97 & 27.11 & 127.42 & $\begin{array}{l}\text { Kuning } \\
\text { Kehijauan }\end{array}$ \\
\hline
\end{tabular}

Pada Tabel 1 memperlihatkan bahwa warna hijau yang ditunjukkan oleh nilai a pada perlakuan bahan penyalut dekstrin konsentrasi 5\% dan 7.5\% mengalami sedikit penurunan sejalan dengan meningkatnya konsentrasi bahan penyalut yang ditunjukan oleh nilai a yang semakin besar. Hal tersebut dikarenakan peningkatan konsentrasi bahan penyalut akan menurunkan proporsi ekstrak pigmen yang digunakan sehingga bahan penyalut menyelimuti warna hijau klorofil dalam bubuk pigmen menurun, oleh karena itu intensitas warna hijau pada bubuk pigmen akan menurun.

Warna hijau pada perlakuan dekstrin konsentrasi $10 \%$ mengalami kenaikan yang dapat dilihat pada Tabel 4. Kenaikan warna hijau yang diperlihatkan oleh nilai a yang semakin negatif ini dikarenakan perlakuan dekstrin 10\% memiliki kadar air terendah dibandingkan dengan perlakuan dekstrin 5\% dan 7.5\% sehingga dapat meningkatkan intensitas warna. Masters (1979) menyatakan bahwa kadar air yang rendah dari produk yang dikeringkan dapat meningkatkan retensi warna.

Nilai HUE pada bubuk pigmen klorofil yang disalut dengan dekstrin terdapat pada daerah kisaran warna yang sama yaitu kuning kehijauan. Hal tersebut menunjukkan bahwa kenaikan 2.5\% belum cukup memberikan perubahan intensitas warna untuk dipantulkan oleh bubuk pigmen klorofil terenkapsulasi dari daun kangkung. Hal tersebut sejalan dengan penelitian Herwindarti (2008) dalam produksi bubuk pigmen antosianin kubis merah yang menunjukkan bahwa peningkatan konsentrasi dekstrin $10 \%$ tidak memberikan pengaruh yang berbeda terhadap nilai HUE bubuk pigmen tersebut.

\subsection{Rendemen}

Analisis rendemen yang dilakukan terhadap bubuk pigmen klorofil dari daun kangkung menunjukan bahwa tiap konsentrasi bahan penyalut yang digunakan menghasilkan rendemen yang relatif sedikit. Rendemen dihitung berdasarkan berat bubuk pigmen yang terbentuk dari volume ekstrak pigmen yang dikeringkan dengan spray dryer. Diagram hasil rendemen bubuk pigmen klorofil dari daun kangkung dapat dilihat pada Gambar 1

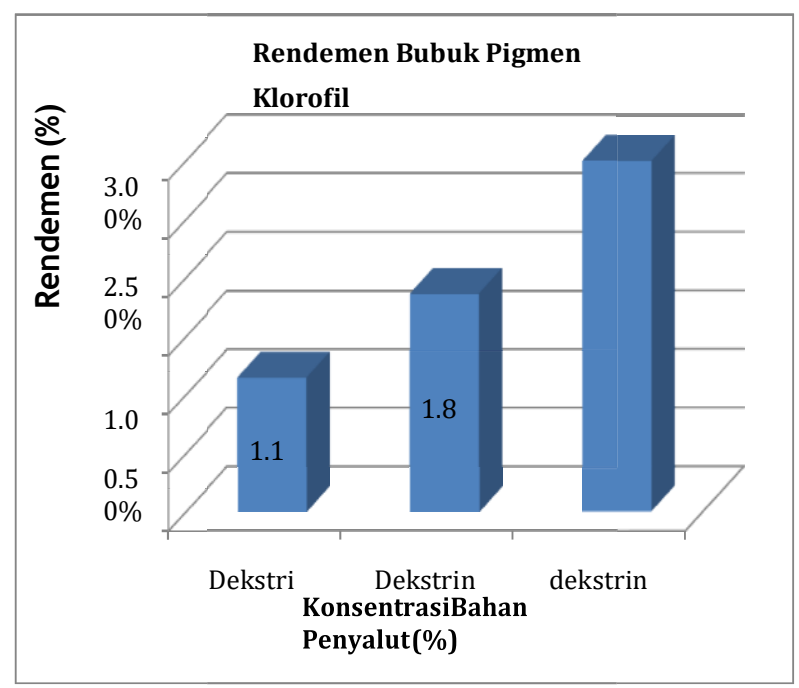

Gambar 1. Rendemen Bubuk Pigmen Klorofil dari Daun Kangkung

Hasil rendemen bubuk pigmen klorofil 
terenkapsulasi pada penelitian ini berkisar dari $1.14 \%-2.99 \%$. Rendemen tersebut termasuk rendah jika dibandingkan dengan rendemen penelitian Wijaya, dkk (1995) tentang pembuatan pewarna dari daun suji dan daun pandan yang memiliki rendemen $2.33 \%$ dengan perbandingan berat padatan dan volume pelarut $(1: 2,5)$ serta disalut dengan dekstrin 1.5\%. Rendahnya rendemen bubuk pigmen disebabkan total padatan dari ekstrak klorofil daun kangkung yang akan dikeringkan rendah. Kandungan total padatan berpengaruh terhadap lama proses pengeringan dan rendemen yang dihasilkan. Makin sedikit total padatan suatu adonan, rendemen bahan akan semakin sedikit (Masters, 1979).

Gambar 13, menunjukkan bahwa semakin tinggi konsentrasi dekstrin yang ditambahkan pada ekstrak klorofil, semakin tinggi pula rendemen yang dihasilkan. Hal ini karena fungsi dekstrin sebagai bahan penyalut, akan meningkatkan kandungan total padatan dalam larutan. Menurut Rahayu (1988) dikutip Sadikin (1993), pada proses pengeringan dengan pengering semprot, peningkatan total padatan akan meningkatkan rendemen produk yang dihasilkan.

Menurut Masters (1979), penambahan bahan penyalut ke dalam suatu larutan dimaksudkan untuk meningkatkan total padatan pada bahan yang dikeringkan. Molekul dekstrin yang bercabang memudahkan gugus hidroksilnya berikatan dengan gugus hidroksil dari pelarut. Pengeringan menggunakan spray dryer menyebabkan pembentukan padatan bersifat sangat halus dan higroskopis. Padatan yang memiliki sifat higroskopis yang tinggi akan mudah menyerap air dari lingkungan yang memiliki kelembaban udara tinggi sehingga menyebabkan padatan menjadi lengket. Besarnya jumlah pelengketan menyebabkan pemindahan bubuk pigmen pada alat pemindahan ke botol penyimpanan semakin sulit sehinnga mengurangi jumlah rendemen akhir yang dihasilkan.

\section{Waktu Rehidrasi}

Waktu rehidrasi yaitu waktu yang dibutuhkan untuk suatu produk larut dalam air, produk yang baik dinilai dari waktu rehidrasi yang semakin singkat dari produk tersebut. Diagram batang waktu rehidrasi bubuk pigmen klorofil terenkapsulasi dari daun kangkung dapat dilihat pada Gambar 16.

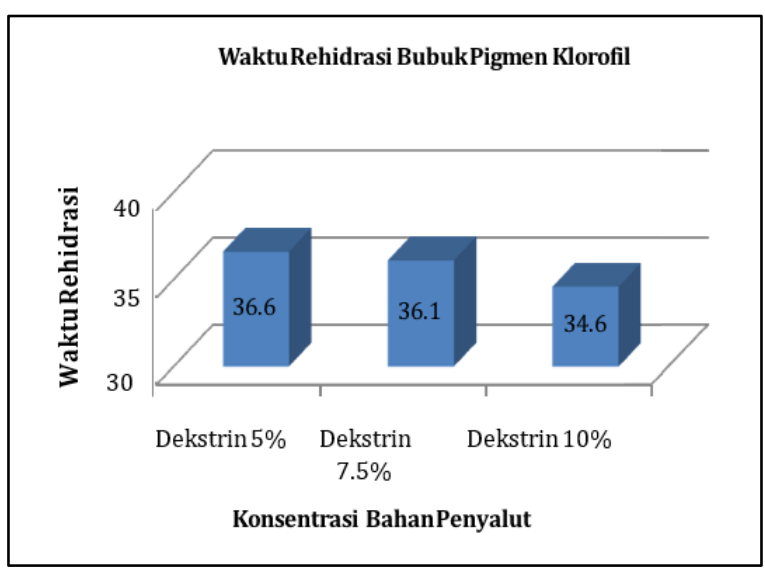

Gambar 16. Waktu Rehidrasi Bubuk Pigmen Klorofil Dari Daun Kangkung

Pada Gambar 16 dapat dilihat bahwa semakin besar konsentrasi dekstrin yang digunakan sebagai bahan penyalut maka waktu rehidrasinya semakin cepat. Hal ini karena semakin banyaknya proporsi dekstrin yang ditambahkan maka cabang gugus hidroksil yang berikatan dengan ikatan hidroksil dalam etanol semakin banyak sehingga mudah untuk dilarutkan.

Molekul dekstrin memiliki struktur rantai pendek berbentuk dan bercabang, sehingga jumlah gugus hidroksil reaktifnya semakin banyak dibandingkan dengan gum arab. Semakin tinggi konsentrasi dekstrin berarti proporsi desktrin yang ditambahkan semakin banyak dan semakin meningkatkan jumlag gugus hidroksil reaktifnya. Jumlah gugus hidroksil reaktif yang banyak akan memperbesar pengikatan air melalui ikatan hidrogen, sehingga lebih cepat (Glicksman, 1969).

\section{Kesimpulan}

Berdasarkan analisis intensitas warna dan rendemen untuk penentuan produk terbaik serta ditunjang dari analisis kadar air, kelarutan, waktu rehidrasi, dan nilai $\mathrm{pH}$, penggunaan dekstrin sebagai bahan penyalut dengan konsentrasi 10\% (b/v) menghasilkan karakteristik bubuk pigmen klorofil daun kangkung terbaik. Karakteristik tersebut adalah memiliki nilai intensitas warna hijau (nilai a) -19.97 dan nilai HUE 127.42 yang berarti berada pada daerah kuning kehijauan, rendemen sebesar $2.99 \%$, kadar air 1,80\%, kelarutan $97.48 \%$, waktu rehidrasi 34.6 detik, dan nilai $\mathrm{pH} 8,1$.

\section{Saran}

Perlu dilakukan penelitian lanjutan mengenai aplikasi bubuk pigmen klorofil dari daun kangkung terhadap sistem pangan, perlakuan proses thermal dan kestabilannya selama penyimpanan 


\section{Daftar Pustaka}

Anonim a. 2007. Lebih Baik Pewarna Alami. Available at : Http://www.scribdt.com. (diakses tanggal 23 April 2009)

Anonim b. 2009. Kangkung. Available at : Http://www.wikipedia.org. (diakses tanggal 23 April 2009)

Anonim c. 2009. Klorofil. Http://www.wikipedia.org (diakses tanggal 23 April 2009).

Antara, N.T. 1994. Ko-kristalisasi Flavor Merupakan Teknik Mikroenkapsulasi yang Paling Mungkin Diterapkan di Indonesia. Prosiding Seminar Sehari "Pelayanan dan Hasil Litbang BBIHP Untuk Masyarakat Industri Hasil Pertanian". Bogor.

AOAC. 1984. Official Methods of Analysis of The Association of Official Analytical Chemist, 14th

Bakan, J.A. 1973. Microencapsulation of Foods and Related Products. J. Food Tech. 22: 34-35.

Buckle, K.A; A. Edwards, G. H. Fleet, M. Woottom. 1987. Ilmu Pangan. UI-Press. Jakarta.

Cahyadi, W. 2006. Analisis dan Aspek Kesehatan Bahan Tambahan Pangan. Penerbit PT. Bumi Aksara. Jakarta.

Chandrayani, E. 2002. Mikroenkapsulasi Oleorisin Biji Pala dengan Menggunakan Sukrosa Sebagai Bahan Penyalut. Skripsi. Jurusan Teknologi Industri Pertanian, Fakultas Teknologi Pertanian. IPB, Bogor.

deMan, J.M. 1997. Kimia Makanan. Penerjemah : Kosasih Padmawinata. Penerbit ITB. Bandung.

Fardiaz, D. 1989. Buku dan Monograf Hidrokoloid. PAU Pangan dan Gizi IPB. Bogor.

Fennema, O. R. 1996. Food Chemistry third Edition. Marcell Decker Inc, New York. Francis, F. J. 1982. Analysis of Anthocianins. dalam Markakis, P. (ed). Anthocianin As Food Colors. Academic Press. New York.

Fridahni, D.T. 2004. Pengaruh pH Alkalis Air Blansing Terhadap Warna Hijau Irisan Helai Daun Bawang Kering. Skripsi. Jurusan Teknologi Industri Pangan, Fakultas Teknologi Industri Pertanian. UNPAD. Jatinangor.

Herwindarti, D. A. 2008. Produksi Bubuk Pigmen Antosianin dari Kubis Merah (Brassica oleraceae Var. Capitata L.F. Rubra (L)phell) dengan Teknik Mikroenkapsulasi. Skripsi. Jurusan Teknologi Industri Pangan, Fakultas Teknologi Industri Pertanian. UNPAD, Jatinangor.

Hutching. J.B. 1999. Food Colour and Appearance. 2nd ed. Aspen Publishing Inc. Maryland.

Hustiany, R. 2006. Teknik Mikroenkapsulasi Untuk Ingredien Pangan. Food Review. 5: 44-47
Jackman, R.L. dan J.L. Smith. 1996. Anthocyanins and Betalains. Dalam Henry,

G.A.F dan J.D. Houghton (ed.). Natural Foods Cholorants. 2nd ed. Blackie Academic \& Proffesional. London.

Keogh, M. K. 2005. Spray Dried Microencapsulated Fat Powders. Dalam Encapsulated and Powdered Foods. Onwulata, C. 2005. CRC Press, USA.

Kim, Y. D dan C.V. Morr. 1996. Microencapsulation Properties of Gum Arabic and Saveral Food Proteins : Spray Dryed Orange Oil Emulsion Particles. J. Agric. Food Chem. 44 : 1314-1320

Masters, K. 1979. Spray Drying Handbook. John Wiley and Sons, New York.

Morrison, R.T dan R.N. Boyd. 1975. Organic Chemistry Third Edition. Prentice Hall of India. New Delhi.

Natalia, D. 2005. Pengaruh Penggunaan Berbagai Jenis Pelarut Organik Terhadap Total Antosianin dari Ekstrak Pigmen Alami Buah Arben (Rubus ideaus (Inn.)). Skripsi. Jurusan Teknologi Industri Pangan, Fakultas Teknologi Industri Pertanian. UNPAD, Jatinagor.

Nurhayati, R.I. 1995. Tinjauan Mengenai Klorofil. Skripsi. Jurusan Farmasi. Fakultas Matematika Dan Ilmu Pengetahuan Alam. UNPAD, Jatinangor.

Othmer, K. 1969. Encyclopedia of Chemical Technology. Vol 3. Wiley Interscience Publication, Jhon Wiley and Son. New York

Pitojo, S. 2008. Khasiat Cincau Perdu. Penerbit Kanisius Jogyakarta.

Pomeranz, Y. 1991. Functional Properties Food Component (2nd ed) Academic Press. Inc,. San Diego. California.

Pratama, F.Y. 2009. Optimasi dan Karakterisasi Pigmen Brazilin Terenkapsulasi Dari Kayu Secang (Caesalpinia sappan Linn). Skripsi. Jurusan Teknologi Industri Pangan. Fakultas Teknologi Industri Pertanian. UNPAD, Jatinangor.

Ridwan, A. 2008. Pengaruh Perbandingan Sukrosa Dengan Sari Kacang Hijau dan Suhu Pengeringan Terhadap Beberapa Karakteristik Mikrokristal Sari Kacang Hijau (Phaseolus radiatus L.). Skripsi. Jurusan Teknologi Industri Pangan, Fakultas Teknologi Industri Pertanian. UNPAD, Jatinangor.

Rosalianty, Helsa. 2008. Produksi Bubuk Pigmen Antosianin Dari Buah Arben (Rubus idaeus (Linn.)) Dengan Teknik Mikroenkapsulasi Menggunakan Dekstrin dan Gum Arab. Skripsi. Jurusan Teknologi Industri Pangan, Fakultas Teknologi Industri Pertanian. UNPAD, Jatinangor. 
Rosenberg, M. 1997. Penemu: The Regents of The University oc California, a California Corporation. 11 Februari 1997. Milk Derived Whey Protein - Based Microencapsulating Agents and Method of Use. US Patent No. 5, 610, 760.

Rukmana, R. 2005. Bertanam Kangkung. Penerbit Kanisius. Jogyakarta

Sadikin, A.C. 1993. Pembuatan Flavor Bubuk Dari Pandan Wangi (Pandanus amarylifolius) Dengan Metode Spray Drying. Skripsi. Fakultas Teknologi Pertanian. IPB, Bogor.

Santoso, H.B. 2008. Ragam dan Khasiat Tanaman Obat. Penerbit Agromedia. Jogyakarta.

Satterwaite, R.W dan D.J. Twinski. 1973. Starch Dextrins. Didalam R.L. Whistler dan J. N. Be Miller. (2nd Ed). Industrial Gum : Polisaccharides and Their Derivates. Academic Press. New York.

Marquez, U. M. L. dan Patricia, S. 2008. Clorpphylls in Food : Sources and Stability. Didalam Socaciu, C. 2008. Food Colorants Chemical and Functional
Properties. CRC Press Taylor and Francis Group. London.

Spicer, A. 1974. Advances in Preconcentration and Dehydration of Food. Applied Science Publ. Ltd. London.

Vargas, F.D. dan Lopez, O.P. 2003. Natural Colorants for Food and Nutraceutical Uses. CRC Press. Washington D.C.

Widiyanti, I. 2004. Pengaruh pH Basa Air Blansing yang Diperoleh dengan NaHCO3 Terhadap Warna Hijau Irisan Bawang Daun. Skripsi. Fakultas Teknologi Industri Pangan. UNPAD, Jatinangor.

Wijaya, C. H., Karina, B., Ni Luh, P. 1995. Penambahan ZnCl2 Dalam Pembuatan Pewarna Bubuk dari Daun Suji dan Daun Pandan. Jurnal Pustaka Teknologi dan Industri Pangan PATPI. Bandung Winarno, F. G. 1997. Kimia Pangan dan Gizi. Penerbit PT. Gramedia Pustaka Utama.Jakarta.

Wirakusumah, E. S. 2006. Buah dan Sayur Untuk Terapi. Penerbit Penebar Swadaya. Jakarta 